\title{
ECOLOGY OF SPHAEROTILUS IN AN EXPERIMENTAL OUTDOOR CHANNEL
}

\author{
John D. Phaup* and John Gannon ${ }^{\dagger}$ \\ Department of Environmental Health, The University of Michigan, \\ Ann Arbor, Michigan, U.S.A.
}

(Received 6 March 1967)

\begin{abstract}
This paper describes ecological investigations performed in an outdoor experimental channel receiving Huron River water and beet sugar or crude molasses during two summers of operation (1965 and 1966).

The channel was assembled in two lengths, $645 \mathrm{ft}$ (1965) and $704 \mathrm{ft}$ (1966), with sampling stations located one near the beginning, one in the middle and one near the end. At each station, three strands of knitting yarn were suspended and allowed to remain for $24 \mathrm{hr}$. After this time, the strands were removed, together with attached growth, and fresh strings replaced. The replicate strings were cut into $10 \mathrm{~cm}$ sections, with one-half of these sections used for dry weight determinations.

The attached organisms were removed by violently shaking the strings suspended in a measured quantity of water. One drop was then removed and direct microscopic counts and identification made immediately. Dry weights were obtained by drying the strings in aluminum weighing pans overnight at $90^{\circ} \mathrm{C}$.

A total of 12 experiments was run, the duration of each being in most cases five days.

In the first series of experiments flow through the channel was at $100 \mathrm{~g} / \mathrm{min}$. at an essentially uniform velocity of $1 \mathrm{ft} / \mathrm{sec}$. Nutrient concentration was varied from $1 \mathrm{mg} / \mathrm{l}$ as sucrose.

In the last series of experiments, nutrient concentration was held at $5 \mathrm{mg} / 1$ and velocity varied at the three stations by altering the height of an overflow weir between 0.0 and $0.6 \mathrm{ft}$, and changing the flow between 25 and $200 \mathrm{~g} / \mathrm{min}$. This provided a range of velocities at the station from 0.09 to $1.49 \mathrm{ft} / \mathrm{sec}$.

The results of attached organism determinations are presented following each experiment and their response to nutrient concentration and velocity summarized in the Discussion.

Sphaerotilus-dominated biological flocs were stimulated to bloom proportions within $30 \mathrm{hr}$ after the addition of as little as $1 \mathrm{mg} / \mathrm{l}$ of sucrose. Maximum growth was obtained at a concentration of $5 \mathrm{mg} / \mathrm{l}$ at velocities from 0.58 to $1.49 \mathrm{ft} / \mathrm{sec}$ in the temperature range of $20-28^{\circ} \mathrm{C}$ after around $72 \mathrm{hr}$ of feeding. About this time, detaching and floating material was equivalent to new material being formed, and the term "saturation population" was proposed to describe this condition.

The biological floc community was composed chiefly of Sphaerotilus natans, Melosira varians, M. granulata, Nitzschia sp., Navicula sp., Cosmarium sp., Euglena sp., and the protozoans, Bodo sp., Tetrahymena pyriformis, Colipidium colpoda, and Amoeba sp., tendipedid and simuliid larval forms also apparently found a mutualistic association within the flocs.

Saturation population and classical Sphaerotilus flocs could not be obtained at temperatures below $17^{\circ} \mathrm{C}$. The typical form was replaced in dominance at low temperatures by an unidentified filamentous bacillus, the total mass of which never approached that of the classical growth.
\end{abstract}

\section{INTRODUCTION}

THERE have been many laboratory investigations into nutrition and biochemistry of Sphaerotilus since the first successful isolation of the organism in pure culture by BüSGEN (1894). Unfortunately, the organism has not been so extensively studied in its natural environment.

\footnotetext{
* Instructor in Environmental Health.

$\uparrow$ Professor of Public Health Engineering.
} 
The ecology of "sewage fungus" was first studied by BuTcHer (1932) who included, in addition to Sphaerotilus, Beggiatoa alba, Thiotrix nivea, several true fungi, the protozoan, Carchesium, and the uncertain organism, "Zooglea ramigera".

LiEBMANN (1951) observed the same associations within the biological floc and asserted that he could determine the age of the floc by the relative abundance of the ciliates, Colpidium colpoda and Glaucoma pyriformis ( = Tetrahymena pyriformis). NaUmann $(1933 a, b)$ attributed these associations to decomposition of the floc.

Perhaps the general consensus at that time was expressed by HARRISON and HEUKELEKIAN (1958) when they stated, referring to the associated organisms in the biological floc, "There is no experimental evidence, however, that any of these accompanying organisms play a significant role in limiting or stimulating the development of the community."

Recently, the biological floc community was studied under simulated stream conditions by ZIMMERMAN (1961) who employed three channels about $243 \mathrm{ft}$ long, 7.9 in. wide, and 5.9 in. deep to study the effects of velocity in biocoenosis. His data suggested that current is more important than pollutional loadings in the composition of the biota in a flowing stream. JAAG and AMBÜHL (1963) tend to support this observation as a result of their research into the effects of current on the macroinvertebrates indigenous to flowing waters.

WUHRMANN (1964) fed sewage in concentration of 2, 4 and 10 per cent in outdoor channels to study the effects of Sphaerotilus in selfpurification. The channels employed in his experiments were about 11.7 in. wide, 7.9 in. deep, $690 \mathrm{ft}$ long with a slope of 0.15 per cent. This provided a discharge of about $126 \mathrm{~g} / \mathrm{min}$. His results indicated that the amount and extent of Sphaerotilus growth was proportional to the concentration of sewage being fed.

HARRISON and HUEUKELEKIAN (1958) reviewed the methods for quantitating slime growth used by various investigators pointing out the difficulties involved in sampling. These techniques involved the use of nets (PoTONIE and WUNDSCH, 1933), glass slides (BUTCHER, 1946), strings (MCKEOWN, 1962), and underwater photography (LIEBMANN, 1953).

The purpose of the present work was first to develop procedures which allowed reliable quantitation of growth of Sphaerotilus and associated organisms under simulated stream conditions; then to determine the effects of nutrient concentration, runoff and velocity on the amount and character of the growth; and lastly to evaluate the role of associated organisms in stimulating or inhibiting the development of a Sphaerotilus bloom.

\section{MATERIALS AND METHODS}

The outdoor experimental channel (FIG. 1) described elsewhere in detail (GANNON et al., 1966) was used in this investigation. In brief, the channel is composed of 4-ft repeating aluminum sections $18 \mathrm{in}$. wide, and made water-tight with a polyvinyl plastic liner. In the first series of experiments, during the summer of $1965,645 \mathrm{ft}$ were used. During the spring-summer of 1966, $704 \mathrm{ft}$ were utilized.

In the first series, sampling stations were installed at three points, No. 1 at $12 \mathrm{ft}$, No. 2 at $314 \mathrm{ft}$, and No. 3 at $625 \mathrm{ft}$, (see FIG. 2 for location). In the second series, four stations were maintained. The locations were: Station No. 1 at $12 \mathrm{ft}$, No. 2 at $240 \mathrm{ft}$, No. 3 at $460 \mathrm{ft}$, and No. 4 at $685 \mathrm{ft}$. 


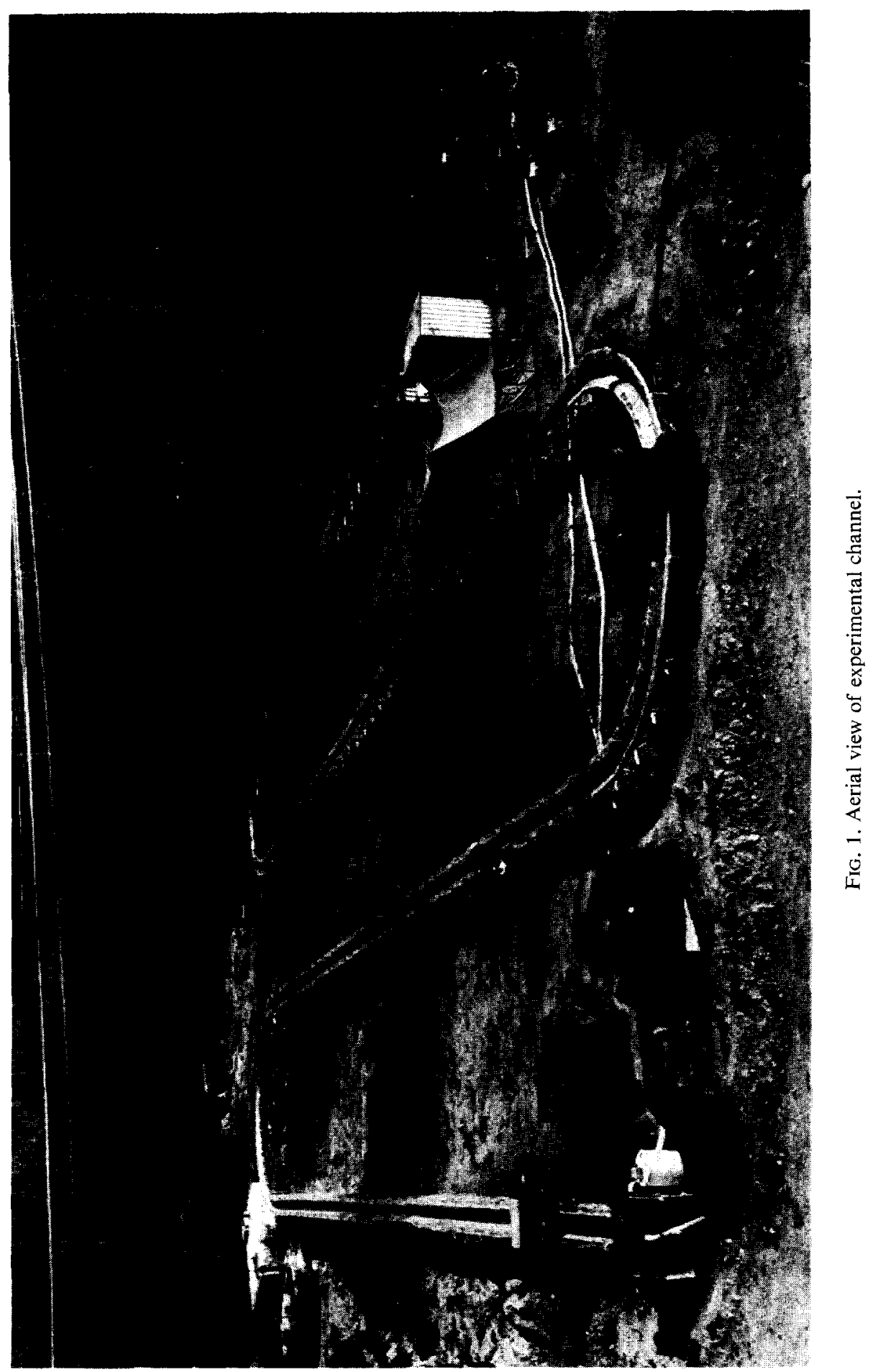

(Facing p. 524) 


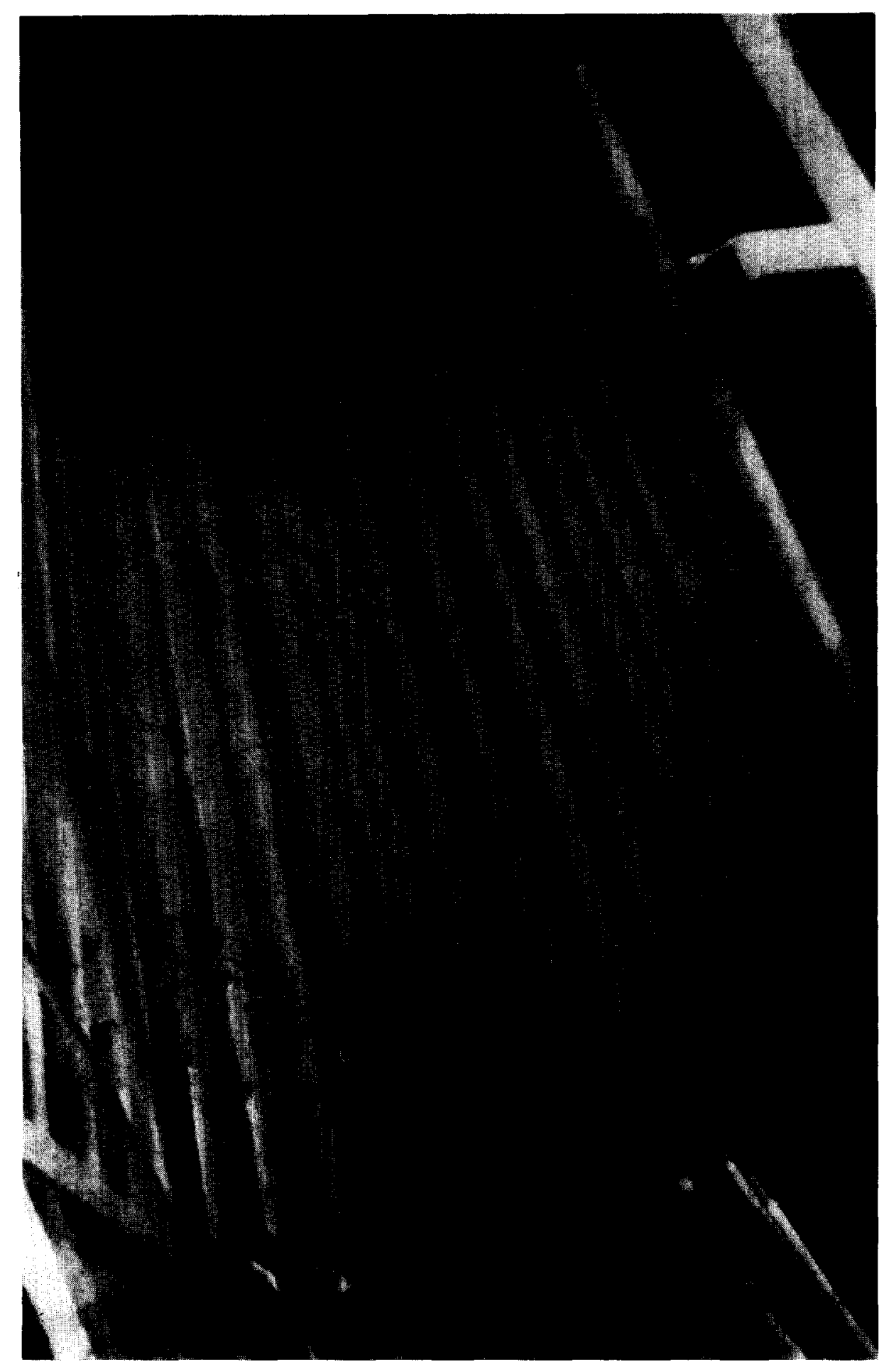

Fig. 3a, Strings at original installation. 


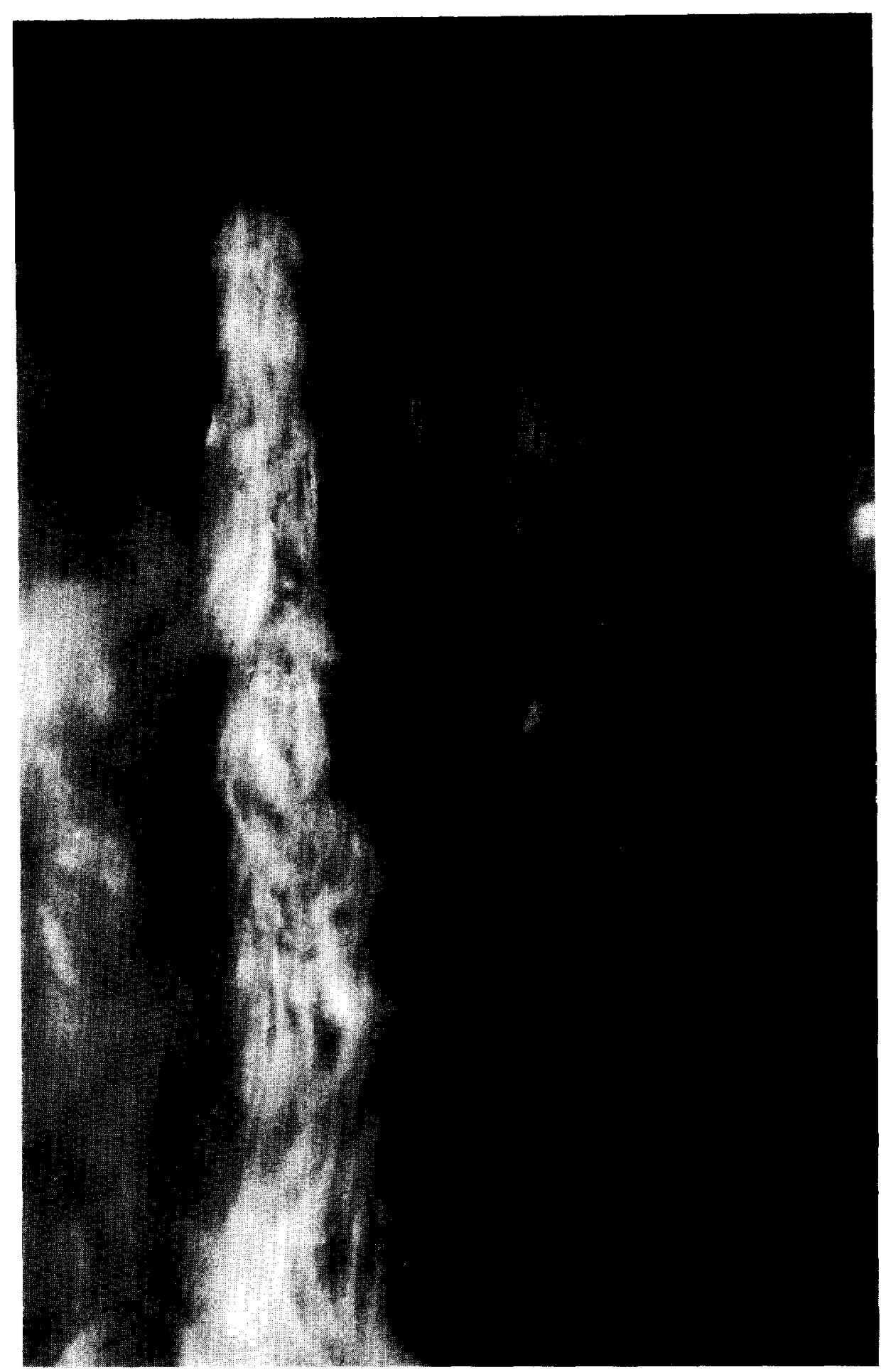

FIG. 3b. Strings during slime building. 


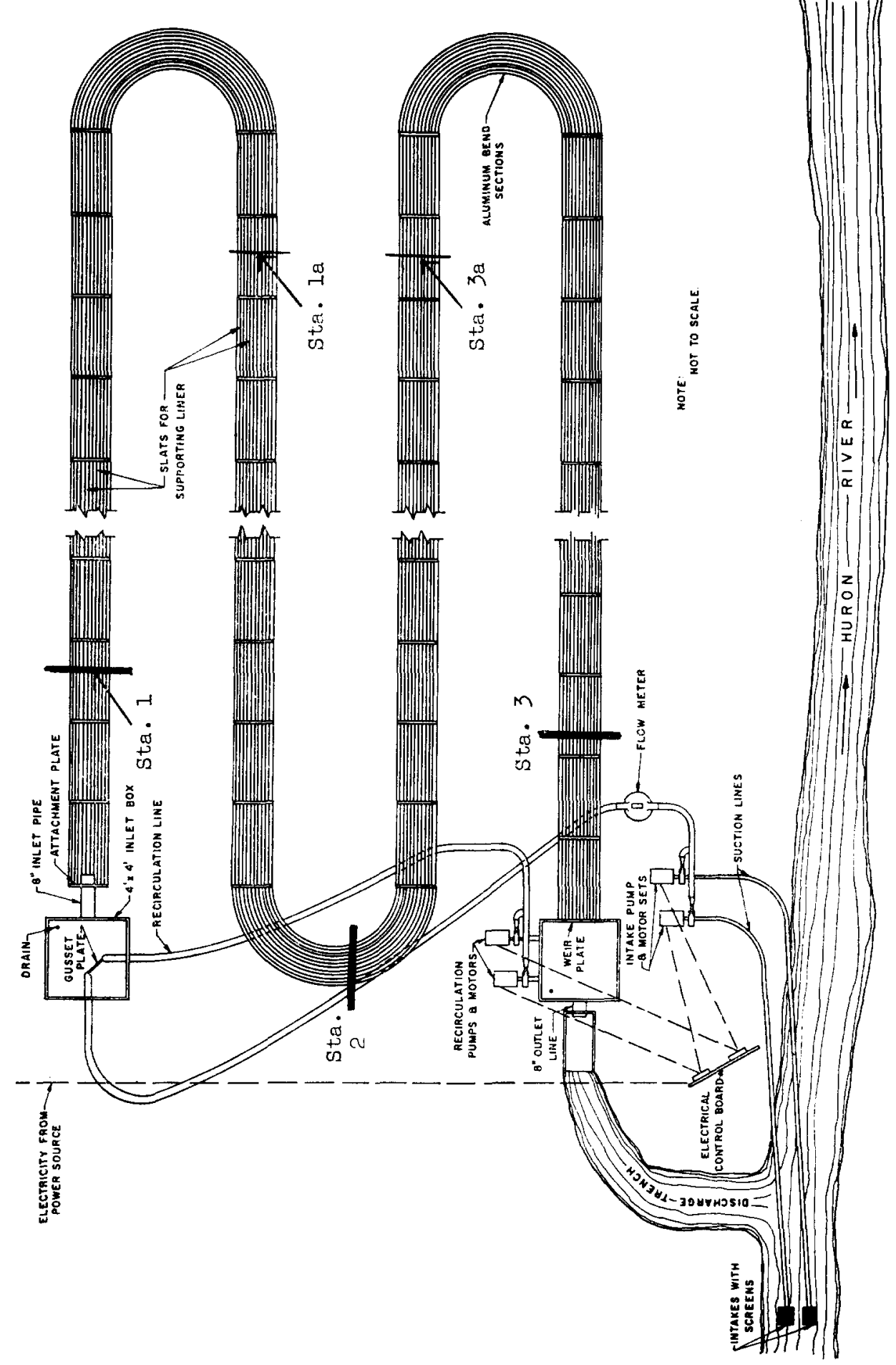

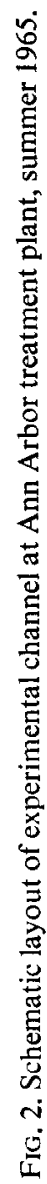


Three strands of Bear Brand Super Spun Nylon 3-ply knitting yarn (Lot No. 3401) were suspended by means of screw hooks from each station and weighted to the plastic liner by heavy hexagonal nuts to a wetted length of about $20 \mathrm{~cm}$. FIGURE 2 illustrates the completed installation.

After the physical and hydraulic characteristics of the channel were defined, one string was removed from each station every $24 \mathrm{hr}$ and replaced with a fresh string. In this manner it was possible to obtain (a) 24-hr strings throughout each experiment and (b) accumulation representing 24-, 48-, and 72-hr growth. However, the 24-hr strings proved to be more satisfactory so all three strings were harvested from each station every $24 \mathrm{hr}$ during the summer of 1966 . This practice offered the additional advantage of providing replicate samples for both dry weights and microscopic determinations.

At the beginning of the experiment, plankton samples were taken daily from an influent sampling valve on the pump and at the overflow weir near the outlet structure. Later, it was found that the plankton apparently did not change significantly in the short time of passage through the channel, so only influent plankton was collected with occasional checks of the effluent. The procedure consisted of removing 3-51. of water and concentrating to $30 \mathrm{ml}$ by means of a No. 20 plankton net. Further concentration and enumeration of organisms was performed following LACKEY's (1938) drop sedimentation technique. Early in the research, samples were preserved in formalin to a final concentration of 4 per cent. This later discontinued and samples were examined within 30 min of collection.

From the strings, two $10 \mathrm{~cm}$ sections were measured and cut. One string with attached growth was resuspended in approximately $4 \mathrm{ml}$ of river water and violently shaken. After discarding the string, the exact number of drops in the sample was counted. One drop was removed with a small bore pipette, placed on a clean glass slide and covered with a No. 1 cover slip. Thus by counting the organisms in one drop and multiplying by the number of drops in the concentrate, it was possible to determine the number of organisms per $10 \mathrm{~cm}$ of string.

The remaining $10 \mathrm{~cm}$ sections of string were placed into weighed aluminum pans, dried overnight in a drying oven at $90^{\circ} \mathrm{C}$ and the dry weight determined. Then by substracting out the known dry weight of unused $10 \mathrm{~cm}$ sections of strings (which was remarkably uniform) the dry weight of the growth per se was obtained.

$\mathrm{pH}$ was continuously monitored in the first series and checked periodically during the second series of experiments.

Temperature was also measured twice daily at each station using a standard mercury thermometer.

Nitrate, nitrite and total nitrogen, along with orthophosphate determinations, were made daily on the influent and effluent channel water in accordance with STANDARD Methods (1965).

Velocities were varied by changing the height of the overflow weir, and velocity determination made using a current meter after each alteration in weir height. Times of passage were measured using a Turner Fluorometer and Rhodamin B dye.

Several sets of hydraulic characteristics were used in this research. In the first series of experiments, flow was maintained at $100 \mathrm{~g} / \mathrm{min}$ free flow on a straight pass through basis giving essentially a uniform velocity of $1 \mathrm{ft} / \mathrm{sec}$. In the second series, flow was from 25 to $200 \mathrm{~g} / \mathrm{min}$ with the overflow weir varied to secure velocities from 1.48 to $0.09 \mathrm{ft} / \mathrm{sec}$ at the stations. 
The first series consisted of five experiments with sucrose concentration as the only variable (except temperature, of course). These concentrations were 1, 5, 10, 20 and $40 \mathrm{mg} / 1$ sucrose in the form of crude molasses or refined beet sugar.

In the second series, $5 \mathrm{mg} / \mathrm{l}$ sucrose was used and the hydraulic characteristics changed as outlined above.

A uniform procedure of operation was adopted which consisted of cleaning the channel thoroughly, admitting river water only at the desired flow for 2 days, then feeding sucrose to give the desired concentration for 4.5 days.

\section{RESULTS}

The Huron River, at the channel site, was rather low in plankton concentration, averaging around 360 per $\mathrm{ml}$. Total dry weight of suspended solids averaged $0.6 \mathrm{mg} / \mathrm{l}$ during the study. The population is far from diverse, partly because the stretch studied, although free-flowing, lies in the backwater of an impoundment.

Because of the relatively short time of passage through the channel, the effluent plankton was essentially the same as the influent, except for a reduction in numbers. This reduction was probably due to the attachment of some organisms to the plastic liner.

Channel water $\mathrm{pH}$ was almost constant at 8.4 during this research, although it varied at times from 8.2 to 8.6 .

Dissolved oxygen (DO) content of influent river water followed a typical diurnal curve, the maximum being attained around 3 p.m. with the minimum occurring around 3 a.m. During the first two to three days of each experiment there was an increase in DO through the channel, the magnitude of which was proportional to the deficit of the incoming water. In some experiments, there was an increase of up to $2.2 \mathrm{mg} / 1$ in $704 \mathrm{ft}$. After this time, when slime growth reached a maximum, a depression occurred, varying from about $0.4 \mathrm{mg} / 1$ to $4.0 \mathrm{mg} / \mathrm{l}$.

Influent channel water varied in total nitrogen from 0.28 to $1.68 \mathrm{mg} / \mathrm{l}$, with a mean value of $0.85 \pm 0.32 \mathrm{mg} / \mathrm{l}$. Nitrate nitrogen ranged from zero to $0.11 \mathrm{mg} / \mathrm{l}$ with a mean of $0.007 \mathrm{mg} / \mathrm{l}$. Nitrite nitrogen varied from zero to $0.16 \mathrm{mg} / \mathrm{l}$, with a mean of 0.016 $\mathrm{mg} / 1$.

Influent ortho-phosphate ranged from 0.001 to $0.01 \mathrm{mg} / \mathrm{l}$.

In most cases there was a reduction in phosphate concentration through the channel in the order of 0.003 to $0.006 \mathrm{mg} / 1$, but there was no discernible pattern to the behaviour of nitrogen through the channel.

\section{Attached organisms}

In the first set of experiments, flow was essentially uniform at $1 \mathrm{ft} / \mathrm{sec}$ throughout the channel, so the attached population at station 2 was considered typical of the entire channel. Preliminary findings indicated this to be a valid assumption.

Although individual organisms were counted, they are expressed in terms of percentages of the total string population; the most frequent genera occurring each day are reported.

\section{Experiment $1(1 \mathrm{mg} / \mathrm{l}$ at $1.0 \mathrm{ft} / \mathrm{sec})$}

Temperature in the channel during this experiment was $15-18^{\circ} \mathrm{C}$.

E W. 
Initially the attached growth was Melosira (33 per cent), Nitzschia (6 per cent), Navicula (3.8 per cent), Ceratium ( 9 per cent), Aphanizomenon ( 5 per cent) and Chlamydomonas with a total of 21 genera present.

Sphaerotilus was evident microscopically at the end of $24 \mathrm{hr}$, while the population was otherwise practically unchanged.

After $48 \mathrm{hr}$, Sphaerotilus was grossly evident, but in a concentration of less than 1 per cent. There was an increase in the green flagellates-Euglena, Phacus and Phacotus. Ceratium increased to 7.5 per cent and Fragilaria.

FIGURE 4 is a presentation of the dry weight increase during the experiment.

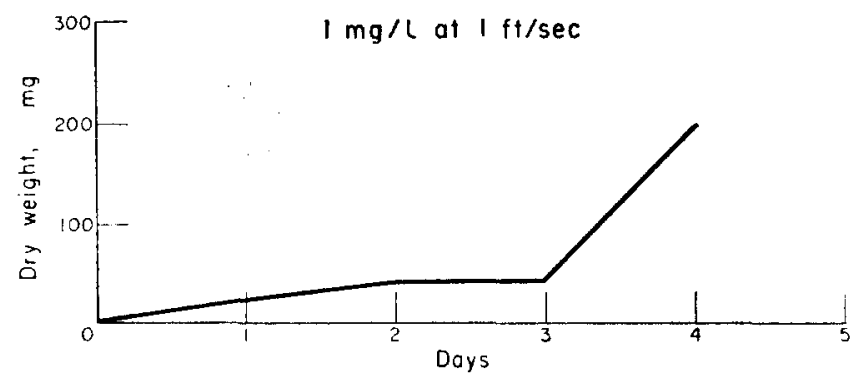

FIG. 4. Dry weight of attached growth.

\section{Experiment $2(5 \mathrm{mg} / \mathrm{l}$ at $1.0 \mathrm{ft} / \mathrm{sec})$}

Water temperatures were in the $20-26^{\circ} \mathrm{C}$ range during this experiment. At the time nutrient feed was initiated the attached population consisted chiefly of Navicula (27 per cent) and Cocconeis (23.3 per cent) together with large numbers of Gyrosigma and Stauroneis. The macroscopic organisms were simuliid larva and pupae, two species of hydropsychids, Culicoides sp., Tendipes spp. and nematodes. In all there were 27 genera.

Twenty-four hours later, strings indicated a population shift from a diverse population, chiefly of diatoms to one predominantly Sphaerotilus (85 per cent) and Melosira (3.5 per cent) with some Anabaena, Ankistrodesmus, Diatoma, Pediastrum and Scenedesmus. There was an increase in simuliid and hydropsychid larvae while the other macroinvertebrate population remained relatively unchanged. There were 14 genera present.

Forty-eight hours after the feed began, Sphaerotilus accounted for about 90 per cent of the population, with Tetrahymena, Nitzschia and Cosmarium increasing. The macroinvertebrates remained in about the same relative numbers. There were 11 genera present.

Attached growth at the end of $72 \mathrm{hr}$ was chiefly Sphaerotilus (90 per cent), Nitzschia, Cosmarium and the protozoan, Tetrahymena, with no significant change in the macroinvertebrates.

At the end of four days, Sphaerotilus represented about 99 per cent of the total biomass of the strings with the remaining 2 per cent consisting of the bacteria-feeding protozoans, Lacrymaria, Tetrahymena and Vorticella; the algae, Nitzschia, Gyrosigma, Mallomonas, Synura and Cosmarium; Tendipes increased about sixfold and planarians made their first appearance. Daphnia, simuliid and hydrosychid larvae were all dead within the flocs when collected. 
By the fifth day of feed, Sphaerotilus had increased to about 99 per cent of the total string biota. There was a tremendous amount of detached and floating Sphaerotilus in the channel and the growth on the strings and channel was anaerobic in the interior. Apparently an equilibrium had been established, such that the amount of material sloughing was about equivalent to the amount of new material formed. The term, "saturation population" was used to describe this condition.

On the sixth day, anaerobic conditions prevailed throughout the attached growth and few other organisms were present other than the protozoans, Tendipes and nematodes. Dry weights are presented in FiG. 5.

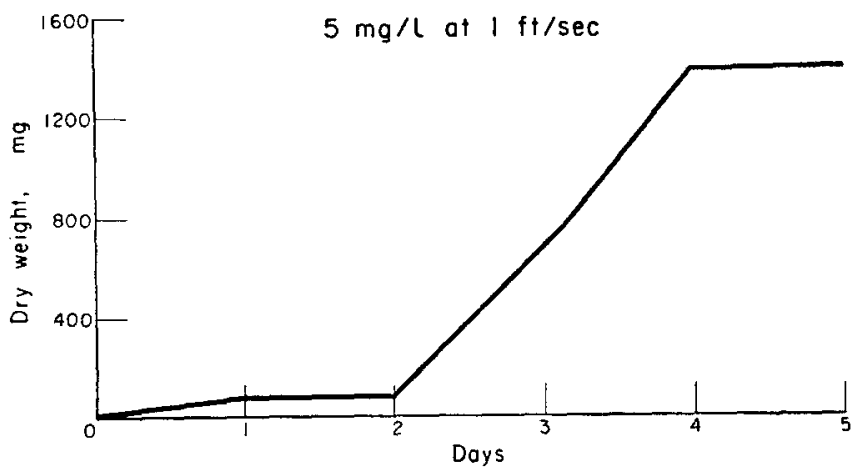

Fig. 5. Dry weight of attached growth.

Experiment $3(10 \mathrm{mg} / 1$ at $1.0 \mathrm{ft} / \mathrm{sec})$

Water temperature in the channel was $27-28^{\circ} \mathrm{C}$ during this experiment.

Before nutrient was added, the populations consisted of Stephanodiscus (26 per cent), Cosmarium (21 per cent), Melosira granulata (18 per cent), Nitzschia (10 per cent), Navicula ( 8 per cent), Melosira varians ( 6 per cent) with the euglenoids-Euglena pisciformis ( 3 per cent) and E. fusca ( 2 per cent), and Phacotus lenticularis ( 1 per cent). Sphaerotilus appeared to the extent of 5 per cent; Vorticella appeared at 1 per cent of the population; Melosira varians increased to 25 per cent while $M$. granulata decreased to 5 per cent, Cymbella increased to 4 per cent and Cosmarium to 22 per cent.

On the second day, Sphaerotilus increased to 80 per cent of the total string population, with a decrease in frequency of the other forms. The number of genera decreased to 13.

After 3 days, Sphaerotilus dominated the population to the extent of 95 per cent. There was a large amount of floating growths indicating that saturation population had occurred. The other organisms remaining were Euglena, Nitzschia and Stephandoiscus, all at 1 per cent along with countless tendipedid larvae. There were 11 genera in all.

On the fourth day of the experiment, Sphaerotilus made up over 95 per cent of the population with the organisms present on the third day still to be found, but considerably reduced in relative numbers. Only 10 genera remained at this time.

Dry weight increase for this experiment is shown in Fig. 6.

Experiment $4(20 \mathrm{mg} / \mathrm{l}$ at $1.0 \mathrm{ft} / \mathrm{sec})$

Channel water temperature was $22-23^{\circ} \mathrm{C}$ during this experiment.

When nutrient feed was started, the population was made up of Melosira varians, Ceratium hirundinella, Aphanizomenon and Fragilaria in that order of magnitude, 
along with Cocconeis, Cymbella, Diatoma, Gomphonema, Navicula, Nitzchia, Pediastrum, Scenedesmus and a macroinvertebrate population of simulii dlarvae, hydropsychids and Tendipes sp. 21 genera were present on the strings.

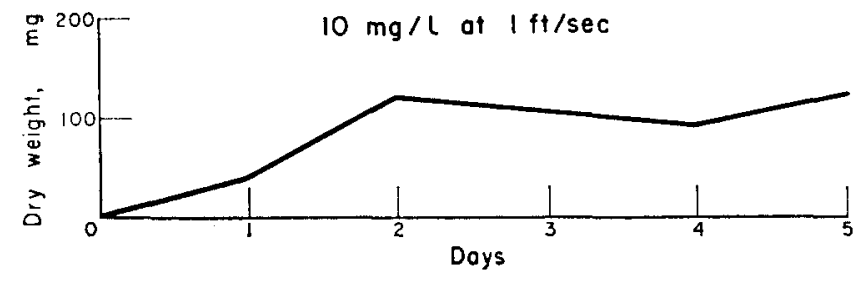

FIG. 6. Dry weight of attached growth.

Twenty-four hours after the introduction of nutrient, string populations consisted of Melosira varians (19.5 per cent), Aphanizomenon (10.4 per cent), Fragilaria (9.7 per cent), Gomphonema, Ceratium hirundinella and Cymbella (8.4 per cent each) with Sphaerotilus following closely behind (5.0 per cent). The macroinvertebrates showed no change except for the appearance of nematodes. The number of genera increased to 31 .

Forty-eight hours post-feed, Sphaerotilus had achieved dominance (33.0 per cent) over Melosira granulata (15 per cent), Aphanizomenon (10.4 per cent), Navicula ( 7 per cent) and Ceratium hirundinella (5 per cent). This growth comprised 22 genera.

After $72 \mathrm{hr}$ of feeding, Sphaerotilus accounted for 70 per cent of the attached population, Melosira varians 9 per cent, Navicula 4 per cent, and Aphanizomenon 3.4 per cent; Tetrahymena, Tabellaria, Scenedesmus, Cymbella and Cosmarium were also present. The population consisted of 20 genera.

Four days after the feed was started the population was chiefly Sphaerotilus ( 90 per cent), Melosira and Navicula. No other genera were represented by significant numbers.

Dry weights for this experiment appear in FIG. 7.

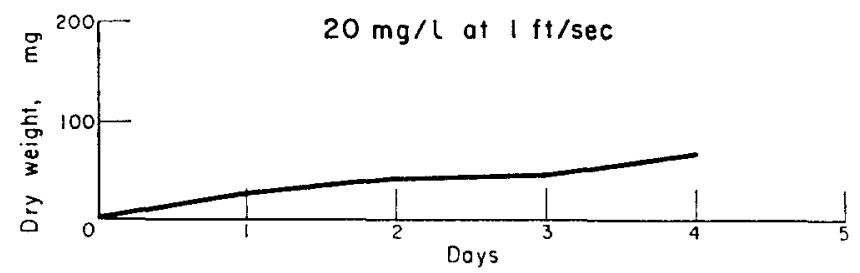

FIG. 7. Dry weight of attached growth.

Experiment $5(40 \mathrm{mg} / \mathrm{l}$ at $1.0 \mathrm{ft} / \mathrm{sec})$

Channel water temperature was $21-24^{\circ} \mathrm{C}$ during this experiment.

When nutrient feed began the string population was composed chiefly of Ceratium hirundinella (46.8 per cent), Melosira granulata (18 per cent), Phacus ( 9 per cent), and the diatoms, Navicula, Surirella, Synedra and Diatoma. Simuliid larvae were the chief macroinvertebrates. A total of 22 genera was present.

At the end of $24 \mathrm{hr}$, the population still consisted chiefly of Ceratium and Melosira with a reduction in other diatoms and the appearance of the myxophyceans, Anabaena circinalis, Aphanizomenon and the rotifers Keratella and Polyarthra. The macroinvertebrates were simuliid and tendipedid larvae. Only 10 genera remained at this time. 
After $48 \mathrm{hr}$ of feeding nutrient, Sphaerotilus was sharing dominance with Ceratium and Melosira. Simuliids and tendipedids increased and two species of hydropsychid larvae appeared. The number of genera was unchanged.

Seventy-two hours after the feed was started, Sphaerotilus was dominant with little change in the associated organisms other than a reduction in numbers.

Four days after the introduction of nutrient, apparently saturation population had been reached, although the magnitude did not approach that obtained with $5 \mathrm{mg} / \mathrm{l}$ sucrose. Sphaerotilus was the dominant organism followed by Ceratium hirundinella and Melosira granulata.

FIGURE 8 indicates dry weight increase during this experiment.

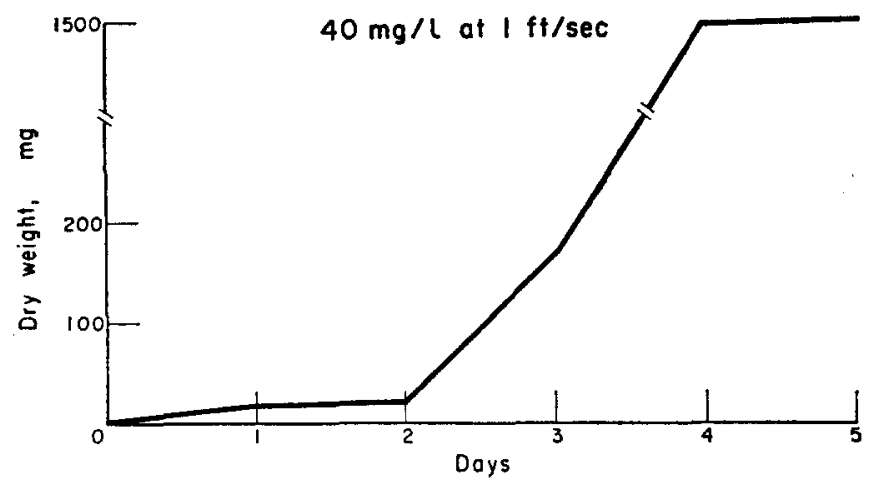

FrG. 8. Dry weight of attached growth.

The second series of experiments was designed to determine the effect of velocity, so sucrose concentration was held constant at $5 \mathrm{mg} / \mathrm{l}$.

Experiment $6(5 \mathrm{mg} / 1$ at $0.09 \mathrm{ft} / \mathrm{sec})$

Temperature was $26-28^{\circ} \mathrm{C}$ during this experiment. The initial population was Stephanodiscus (30 per cent), Amoeba ( 8 per cent) and Melosira granulata (3 per cent) along with Bodo, Pedistrum and Pandorina. There were 16 genera present.

After receiving nutrient for $24 \mathrm{hr}$, Sphaerotilus was present and Stephanodiscus decreased to 10 per cent. Other organisms were reduced in numbers while Chlorella, Difflugia, Fragilaria, Scenedesmus and Staurastrum disappeared. Only 8 genera remained.

On the second day, Sphaerotilus was 10 per cent of the attached population; Stephanodiscus and Euglena were 2 per cent each; Oscillatoria reappeared and Sphaerocystis was no longer present. Seven genera remained.

By the third day Sphaerotilus had increased to 25 per cent of the population, which consisted of Oscillatoria, Euglena, Bodo, Tetrahymena with the bacteria Beggiatoa and Spirillum sp. Tendipes, Nais and adult hydrophilids were the macroinvertebrates.

The population was unchanged on the fourth and final day of the experiment. Black granular sludge with an odor of hydrogen sulfide was present throughout the channel at the conclusion of this experiment. The dry weights of attached growth appear in FIG. 9.

\section{Experiment $7(5 \mathrm{mg} / 1$ at $0.29 \mathrm{ft} / \mathrm{sec})$}

Channel water temperature was also $26-28^{\circ} \mathrm{C}$ during this experiment.

The initial population consisted of Stephanodiscus (20 per cent), Melosira granulata 
(15 per cent), Navicula (10 per cent) with Amoeba, Boda, Chilomonas and Cosmarium. Tendipes and hydrophilids were the macroinvertebrates. In all, 18 genera were present. After $24 \mathrm{hr}$, Sphaerotilus was noted with a reduction in numbers of other organisms. Melosira varians, Chlorella, Coelastrum, Coleps and Cosmarium were no longer present. The number of genera decreased to 12 .

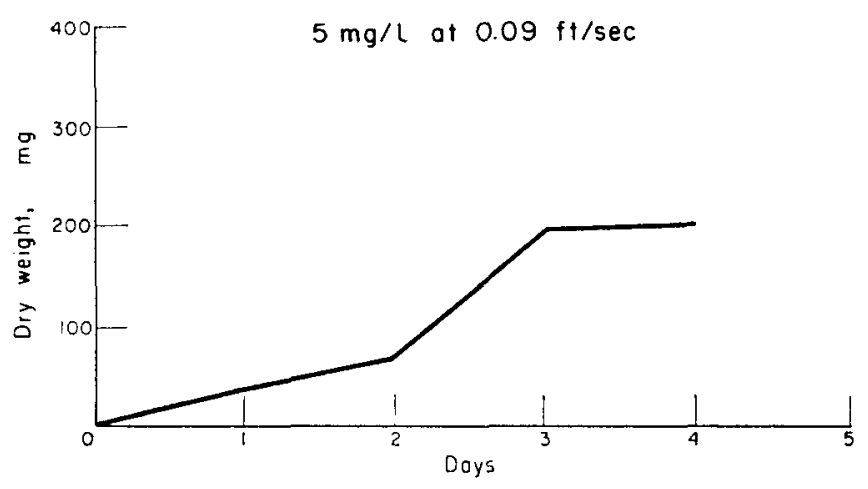

FIG. 9. Dry weight of attached growth.

On the third day of feeding, Sphaerotilus had increased to 20 per cent of the population with Stephanodiscus (5 per cent) the only organism remaining in quantity.

Four days after the feed was started, Sphaerotilus amounted to 80 per cent of the population, followed in dominance by Tetrahymena (1 per cent). Euglena and Oscillatoria were observed in quantity along with Beggiatoa and Spirillum. Nais, Tendipes and the hydrophilids were the only macroinvertebrates.

FIGURE 10 is a graphical presentation of the results of dry weight determinations.

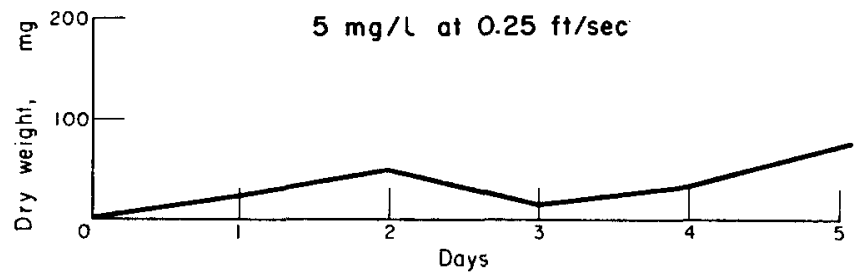

FIG. 10. Dry weight of attached growth.

Experiment $8(5 \mathrm{mg} / 1$ at $0.39 \mathrm{ft} / \mathrm{sec})$

Channel water temperature during this experiment was $26-27^{\circ} \mathrm{C}$.

Before adding nutrient the string population was Melosira varians and M. granulata at 25 and 20 per cent respectively, along with Stephanodiscus (15 per cent), Cosmarium (6 per cent), Oscillatoria ( 5 per cent) and Schroederia ( 2 per cent). Twenty-one genera were present in the string population.

After $24 \mathrm{hr}$ of receiving nutrient, strings showed Sphaerotilus at 2 per cent of the population. Stephanodiscus increased to 30 per cent, Cosmarium to 20 per cent, Nitzschia to 5 per cent. Other organisms generally decreased. One hydrophilid beetle was seen and some midge eggs appeared on the strings. Twenty genera were present.

At the end of $48 \mathrm{hr}$ Sphaerotilus accounted for 70 per cent of the population on the strings with Stephanodiscus second in dominance at 10 per cent. Still present in large 
numbers were Cosmarium ( 8 per cent) Nitzschia ( 5 per cent), Navicula ( 3 per cent) and Vorticella ( 3 per cent). Again large quantities of midge eggs were present with one scavenger beetle noted. The number of genera dropped to 17 .

Three days after nutrient feed began, Sphaerotilus reached 90 per cent of the total attached organisms at this station. Only Stephanodiscus (5 per cent), Cosmarium (3 per cent and Oscillatoria (1 per cent) remained in quantity. Neither Melosira granulata nor $M$. varians were observed at this time. Other than their disappearance, along with that of Ulothrix, there was merely a reduction in numbers from that observed on the second day. The number of genera present dropped to 13 .

On the fourth and final day of nutrient feed, Spaerotilus was 98 per cent of all attached organisms. Although the organisms present were the same as the third day, none amounted to 1 per cent of the population, and the number of genera remaining dropped to 11 .

Dry weights for this experiment appear in FIG. 11.

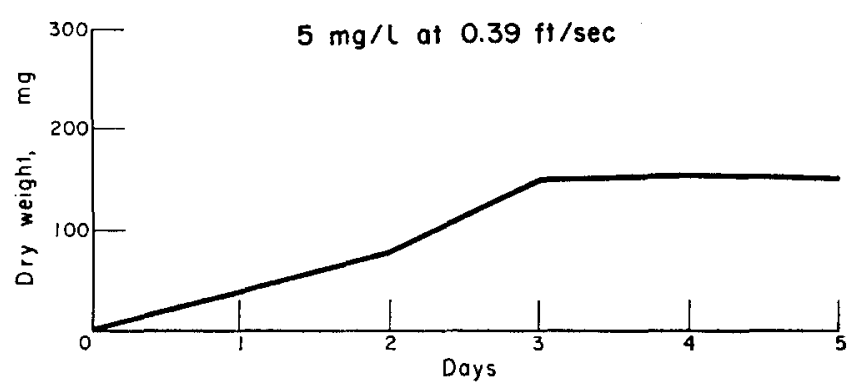

FIG. 11. Dry weight of attached growth.

Experiment $9(5 \mathrm{mg} / 1$ at $0.50 \mathrm{ft} / \mathrm{sec})$

The temperature of the channel water during this experiment was also $26-27^{\circ} \mathrm{C}$.

The initial population before nutrient was introduced consisted of Melosira varians, M. granulata and Stephanodiscus at 27, 22 and 18 per cent respectively, along with Cosmarium, Navicula and Oscillatoria at about 5 per cent each. This population comprised 22 genera.

Twenty-four hours later Sphaerotilus was present but less than 1 per cent of the total population; Cosmarium increased to 18 per cent; Stephanodiscus to 28 per cent; Nitzschia to 10 per cent and Navicula to 8 per cent, while Melosira varians decreased to less than 1 per cent. Euglena fusca appeared at 5 per cent. Coelastrum, Tetrahymena and Colpidium made their appearance. The number of genera remained at 22.

After $48 \mathrm{hr}$ of feeding, Sphaerotilus had increased to 60 per cent of the string population, with Stephanodiscus at 20 per cent and Cosmarium at 10 per cent. Next in dominance were Melosira granulata (3 per cent), Euglena fusca ( 2 per cent) and Melosira varians ( 1 per cent). A small number of Euplotes eurystomas were present within the floc. Midge cases were noted attached to all strings at all stations. The number of genera decreased to 16 .

On the third day of feeding, Sphaerotilus increased to 85 per cent of the attached population followed by Stephanodiscus ( 8 per cent), Cosmarium ( 5 per cent), and Phacus at 3 per cent. Closterium appeared in small numbers, while amoebas were no longer found. Only 13 genera remained. 
At the end of four days, Sphaerotilus amounted to 98 per cent of the population with only Stephanodiscus (1 per cent) at one per cent or more of the total. The other organisms remained, but were reduced in numbers. The number of genera present remained 13.

FIGURE 12 is a presentation of dry weights for this experiment.

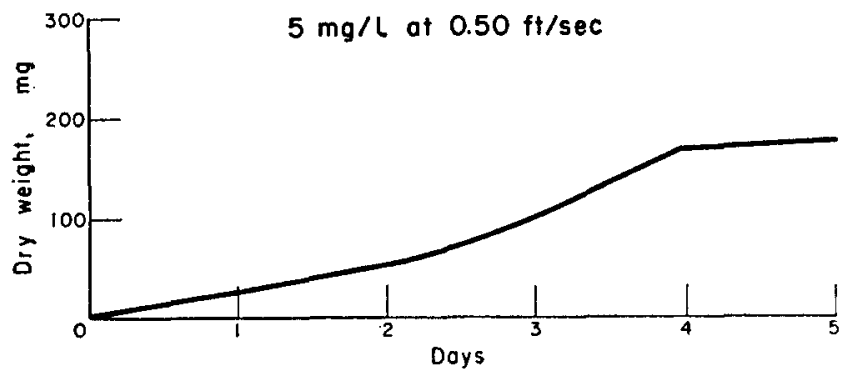

FIG. 12. Dry weight of attached growth.

Experiment $10(5 \mathrm{mg} / \mathrm{l}$ at $0.58 \mathrm{ft} / \mathrm{sec})$

Channel water temperature was $26-27^{\circ} \mathrm{C}$ during this experiment.

Before the feed was started, the attached organisms were Melosira varians, (30 per cent), $M$. granulata (20 per cent) and Stephanodiscus (15 per cent). Cosmarium, Nitzschia and Oscillatoria were present at 5 per cent each.

After nutrient was added for $24 \mathrm{hr}$, Sphaerotilus appeared in quantity ( 5 per cent), Colpidium increased to 15 per cent, Stephanodiscus to 30 per cent and Nitzschia to 10 per cent while the other organisms showed little change. The number of genera present dropped to 14 .

At the end of $48 \mathrm{hr}$ of feeding, Sphaerotilus had reached bloom proportions (70 per cent) with Stephanodiscus and Melosira varians at 10 per cent each. Cosmarium (5 per cent, and Oscillatoria (2 per cent) were still present in numbers and Ulothrix appeared at 2 per cent. The number of genera had decreased from 28 before feed began to 10 .

Three days after nutrient feed was started Sphaerotilus dominated the population to the extent of 90 per cent, followed by Stephanodiscus ( 5 per cent) Cosmarium ( 3 per cent), and Oscillatoria (1 per cent). Representatives of only 8 genera remained.

On the fourth day of feeding, Sphaerotilus reached saturation population amounting to 98 per cent of the attached population. The population was essentially the same as the third day except for a reduction in numbers. The attached population consisted of 8 genera.

FIGURE 13 shows the dry weight increase for this experiment.

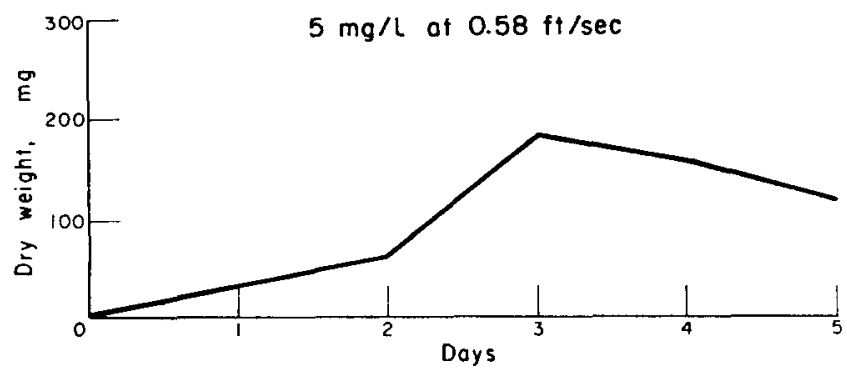

FIG. 13. Dry weight of attached growth. 
Experiment $11(5 \mathrm{mg} / 1$ at $0.72 \mathrm{ft} / \mathrm{sec})$

Temperature during this experiment averaged $26-28^{\circ} \mathrm{C}$.

The initial population was composed of Melosira varians (30 per cent), M. granulata (25 per cent), Stephanodiscus (20 per cent), Cosmarium (15 per cent), Euglena fusca ( 5 per cent) and Ulothrix ( 2.5 per cent). Twelve genera were present in the population.

After $24 \mathrm{hr}$ of feeding, Sphaerotilus appeared at 10 per cent. Ulothrix increased to 5 per cent; Oscillatoria increased to 3 per cent and Euglena was no longer found. The total number of genera remained unchanged at 12 .

Forty-eight hours of nutrient feed produced a bloom of Sphaerotilus (90 per cent), with only Melosira varians (5 per cent), Cosmarium (2 per cent), Stephanodiscus (1 per cent) and Ulothrix (1 per cent) remaining in numbers. The attached population consisted of 9 genera.

After 3 days of receiving nutrient Sphaerotilus was 98 per cent of the attached population. No other organism was present at 1 per cent of the total. Only 5 genera made up the population.

On the fourth day Sphaerotilus was dominant to the extent of 99 per cent with the organisms present on the third day still persisting but in relative numbers. The number of genera remained at 5 .

Dry weight increase for this experiment is presented in Fig. 14.

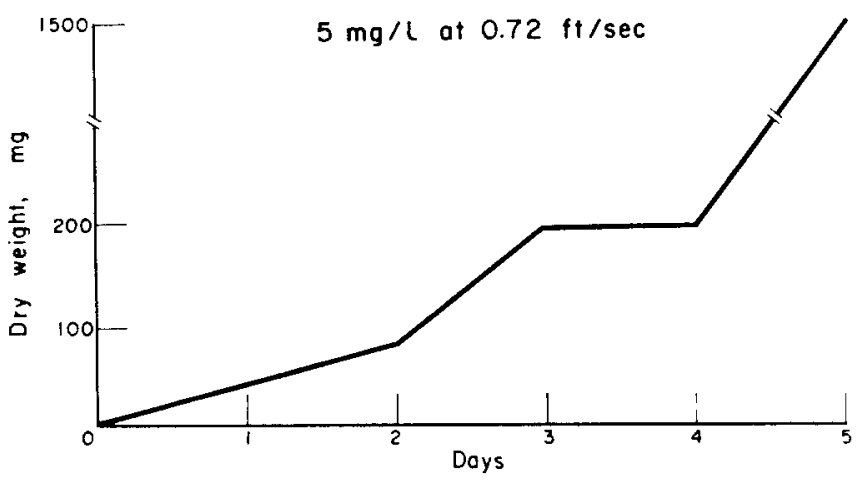

FIG. 14. Dry weight of attached growth.

Experiment $12(5 \mathrm{mg} / \mathrm{l}$ at $1.48 \mathrm{ft} / \mathrm{sec})$

Temperature of the channel water was somewhat variable during this experiment ranging from $23-26^{\circ} \mathrm{C}$.

Before nutrient feed was initiated, the population consisted of 14 genera. The predominant organisms were Melosira varians (40 per cent), Melosira granulata (30 per cent), Cosmarium (10 per cent), Oscillatoria ( 5 per cent), Navicula ( 3 per cent) and Nitzschia (2 per cent).

After being fed for $24 \mathrm{hr}$, Sphaerotilus was present at 55 per cent of the population. Oedogonium appeared at 3 per cent, Ulothrix at 5 per cent, and Stigeoclonium tenue at 15 per cent. Thirteen genera were present.

On the second day, Sphaerotilus increased to 80 per cent, sharing dominance with Stigeoclonium (15 per cent), Ulothrix, Oedogonium, Melosira granulata and Nitzschia were no longer observed in the string population. Tendipes were abundant on the strings and sides of the liner. Genera present decreased to 8 in number. 
Three days after feed began, Sphaerotilus dominated the population to the extent of 99 per cent. Stigeoclonium (1 per cent) was the only organism remaining in quantity, although the total number of genera remained at 8 .

On the fourth and final day, the attached population was 99 per cent Sphaerotilus with salml amounts of Stigeoclonium, Nitzschia, Cosmarium, the ciliates-Colpidium and Tetrahymena, and of course the tendipedid larvae. Growths were decomposed and the number of genera in the population dropped to 5 .

Detailed results of this experiment appear in FIG. 15.

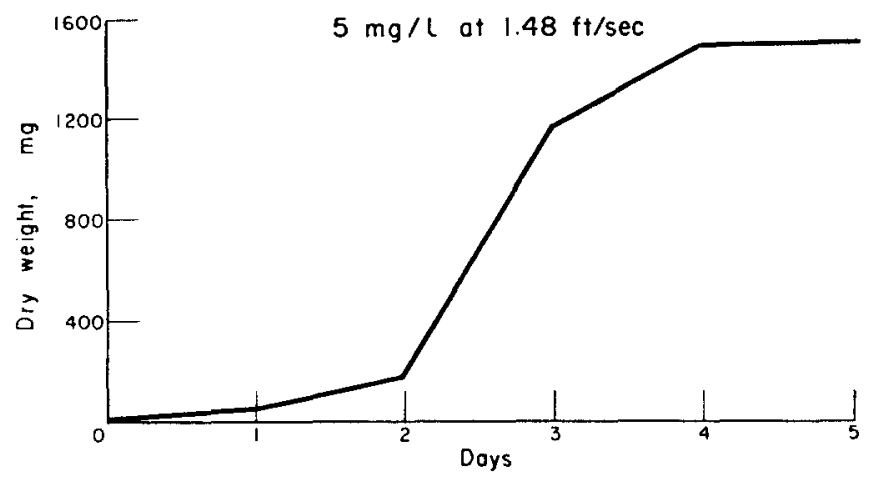

FIG. 15

DISCUSSION

The string method appears to be a reasonably reliable method of making quantitative measurements of growth and enumerating the organisms associated with slime buildup. This possesses the advantages of the submerged slide technique but does not appreciably alter the hydraulic characteristics of the channel as does the latter. Of all materials tested in a prototype flume (glass rods, slides, sticks, nets, etc.), this method gave as reproducible results as any. The reproducibility obtained between duplicate dry weights in the channel was of the order of \pm 5 per cent for samples in the range of $25-100 \mathrm{mg}$; about 10 per cent in the range $100-300 \mathrm{mg}$; becoming \pm 30 per cent in the range $300-1000 \mathrm{mg}$. Dry weights greater than $1000 \mathrm{mg}$ varied as much as $50-60$ per cent between replicates.

Reproducibility as far as enumeration of the attached organisms is concerned is, of course, dependent on several additional factors and would be difficult to assess directly.

The string idea is not new; it has been used by many investigators, but the use of nylon knitting yarn seems to be a novel approach. When viewed microscopically, each of the strands is made up of thousands of individual fibers radiating in all directions, each presenting a potential attachment site. This fine structure contributes the rough feel to the yarn, and because of this structure, the surface area of each $10 \mathrm{~cm}$ section is tremendous. Due to the large surface area, the yarn is able to support much more massive growths than a smooth string.

It is felt that the technique of expressing results as percentage of attached growth per $10 \mathrm{~cm}$ of yarn is a valid and useful one. Since the strings afford an equal opportunity for attachment to the incoming biota for $24 \mathrm{hr}$, their frequency is governed only by current, tolerance and generation time. 
Counting becomes very difficult when dealing with massive quantities of Sphaerotilus. It is often necessary to dilute the material several-fold to free the associated organisms of their entanglement in the filaments.

The chief response of the attached organisms to nutrient addition and/or Sphaerotilus growth was a reduction in genera. Following is a list of frequent planktonic and channel forms and their response to nutrient and velocity:

Anabaena circinalis: Common river plankter in August; lacking in July, September and October. Fair channel growth at $10 \mathrm{mg} / 1$ and a velocity of $0.68 \mathrm{ft} / \mathrm{sec}$; slight growth at $5 \mathrm{mg} / \mathrm{l}$ and a velocity of $1 \mathrm{ft} / \mathrm{sec}$.

Ankistrodesmus sp.: Relatively abundant in early August, present throughout July, August, September and October in river plankton. Excellent channel growth at $10 \mathrm{mg} / 1$ and $0.68 \mathrm{ft} / \mathrm{sec}$; slight growth at $5 \mathrm{mg} / \mathrm{l}$ and velocities from 0.29 to $0.58 \mathrm{ft} / \mathrm{sec}$.

Aphanizomenon sp.: Common in river plankton in late August through September. Excellent channel growth at $20 \mathrm{mg} / \mathrm{l}$ and a velocity of $1 \mathrm{ft} / \mathrm{sec}$ and at $10 \mathrm{mg} / 1$ and a velocity of $0.25 \mathrm{ft} / \mathrm{sec}$.

Asterionella formosa: Present in river plankton in early October. Excellent channel growth at $10 \mathrm{mg} / \mathrm{l}$ and $0.71 \mathrm{ft} / \mathrm{sec}$.

Ceratium hirundinella: Most common river plankter in August through October. Best channel growth at $40 \mathrm{mg} / 1$ and a velocity of $1 \mathrm{ft} / \mathrm{sec}$.

Chlorella sp.: Present in river plankton in August and September. Good channel growth at a velocity of $1 \mathrm{ft} / \mathrm{sec}$ and a sucrose concentration of $1,5,10$ and $20 \mathrm{mg} / \mathrm{l}$.

Chlamydomonas sp.: Common river plankter in July, August and September. Fair growth at $1 \mathrm{ft} / \mathrm{sec}$ with concentrations of 5,10 and $20 \mathrm{mg} / \mathrm{l}$.

Closterium sp.: Noted in river plankton in mid-August. Fair channel growth at $20 \mathrm{mg} / \mathrm{l}$ and a velocity of $1 \mathrm{ft} / \mathrm{sec}$. Slight growth at all velocities tested at 5 and $10 \mathrm{mg} / \mathrm{l}$.

Cocconeis sp.: Present in river plankton in mid-August. Fair channel growth at $20 \mathrm{mg} / 1$ sucrose and $1 \mathrm{ft} / \mathrm{sec}$ velocity, and $5 \mathrm{mg} / 1$ at 0.76 and $0.5 \mathrm{ft} / \mathrm{sec}$.

Cryptomonas ovata: Present in river plankton throughout August. Fair channel growth at $20 \mathrm{mg} / 1$ and $1 \mathrm{ft} / \mathrm{sec}$ velocity.

Cyclotella sp.: Not frequently observed in river plankton. Slight channel growth at $5 \mathrm{ml} / \mathrm{l}$ sucrose and $1 \mathrm{ft} / \mathrm{sec}$ and $10 \mathrm{mg} / \mathrm{l}$ with velocities of 0.68 and $1 \mathrm{ft} / \mathrm{sec}$.

Cymbella sp.: Observed in river plankton in August. Good channel growth at 5, 10 and $20 \mathrm{mg} / \mathrm{l}$ and $1 \mathrm{ft} / \mathrm{sec}$ and at $5 \mathrm{mg} / 1$ and 0.25 to $0.58 \mathrm{ft} / \mathrm{sec}$.

Cymatopleura sp.: Present in river plankton in August. Good channel growth at $5 \mathrm{mg} / \mathrm{l}$ sucrose and velocities of 0.56 and $0.68 \mathrm{ft} / \mathrm{sec}$. Fair growth at 5 and $10 \mathrm{mg} / \mathrm{l}$ at 0.25 and $0.71 \mathrm{ft} / \mathrm{sec}$ respectively.

Diatoma vulgare: Present in river plankton in August and September. Good channel growth at 5,10 and $20 \mathrm{mg} / 1$ and $1 \mathrm{ft} / \mathrm{sec}$ and at $5 \mathrm{mg} / \mathrm{l}$ at $0.25 \mathrm{ft} / \mathrm{sec}$.

Difflugia sp.: Present in river plankton in July, August and September. Fair channel growth at $10 \mathrm{mg} / 1$ sucrose and $0.71 \mathrm{ft} / \mathrm{sec}$.

Dinobryon sertularia: Present in river plankton in August and October. Fair channel growth at $10 \mathrm{mg} / \mathrm{l}$ sucrose and 0.71 , or $1 \mathrm{ft} / \mathrm{sec}$.

Desmidium sp.: Present in river plankton in late August. Slight channel growth at 20 and $40 \mathrm{mg} / \mathrm{l}$ sucrose and $1 \mathrm{ft} / \mathrm{sec}$ and at $5 \mathrm{mg} / 1$ at $0.58 \mathrm{ft} / \mathrm{sec}$.

Euglena sp.: Present in river plankton in August and September. Slight channel growth at all concentrations and velocities tested; best growth at $5 \mathrm{mg} / \mathrm{l}$ and $0.76 \mathrm{ft} / \mathrm{sec}$. 
Fragilaria crotonensis: Abundant in river plankton in September and October. Excellent channel growth at $1 \mathrm{mg} / \mathrm{l}$ and $1 \mathrm{ft} / \mathrm{sec}$ and at $5 \mathrm{mg} / 1$ and $0.58 \mathrm{ft} / \mathrm{sec}$.

Gomphosphaeria aponina: In plankton during early and mid-October. Slight growth in channel at 20 and $1 \mathrm{mg} / 1$ sucrose and $1 \mathrm{ft} / \mathrm{sec}$; at $10 \mathrm{mg} / 1$ sucrose at 0.71 and 0.25 $\mathrm{ft} / \mathrm{sec}$ at $5 \mathrm{mg} / 1$ and $0.58 \mathrm{ft} / \mathrm{sec}$.

Keratella sp.: Occasionally in river plankton in July through September. Slight channel growth at $40 \mathrm{mg} / \mathrm{l}$ sucrose at $1 \mathrm{ft} / \mathrm{sec}$.

Lyngbya sp.: Present in river plankton during October. Good channel growth at $10 \mathrm{mg} / \mathrm{l}$ sucrose at $0.68 \mathrm{ft} / \mathrm{sec}$.

Melosira granulata: Dominant river plankter in July through September. Excellent channel growth at $1 \mathrm{mg} / 1$ and $5 \mathrm{mg} / 1$ at $1 \mathrm{ft} / \mathrm{sec}$ and at $10 \mathrm{mg} / \mathrm{l}$ sucrose at 0.71 and $0.25 \mathrm{ft} / \mathrm{sec}$.

Melosira varians: Common plankter in August through late October. Excellent channel growth at 5,10 and $20 \mathrm{mg} / 1$ at all velocities except $0.09 \mathrm{ft} / \mathrm{sec}$.

Microspora sp.: Not observed in river plankton. Excellent channel growth at 5 $\mathrm{mg} / \mathrm{l}$ and $1 \mathrm{ft} / \mathrm{sec}$.

Navicula sp.: Common river plankter in July, August and September. Good channel growth at 1,5 and $10 \mathrm{mg} / 1$ sucrose with velocities from 0.29 to $1 \mathrm{ft} / \mathrm{sec}$. Best growth at $10 \mathrm{mg} / \mathrm{l}$ and $1 \mathrm{ft} / \mathrm{sec}$.

Nitzschia sp.: Common river plankter in August and September. Excellent channel growth at $10 \mathrm{mg} / 1$ sucrose and 0.71 , and $1 \mathrm{ft} / \mathrm{sec}$; slight growth down to $0.29 \mathrm{ft} / \mathrm{sec}$ at $5 \mathrm{mg} / \mathrm{l}$.

Oscillatoria sp.: Present in river plankton in October. Excellent channel growth at $5 \mathrm{mg} / \mathrm{l}$ with velocities from 0.56 to $0.71 \mathrm{ft} / \mathrm{sec}$. Good growth at all velocities with concentrations of 1 and $10 \mathrm{mg} / \mathrm{l}$.

Pediastrum sp.: Present in river plankton in July through October. Slight channel growth at $10 \mathrm{mg} / \mathrm{l}$ sucrose with velocities of $0.71,0.68$ and $0.25 \mathrm{ft} / \mathrm{sec}$ and at 5,20 , and $40 \mathrm{mg} / 1$ at $1 \mathrm{ft} / \mathrm{sec}$.

Phacus sp.: Present in river plankton in July through September. Good channel growth at $1 \mathrm{mg} / \mathrm{l}$ sucrose and $1 \mathrm{ft} / \mathrm{sec}$ velocity.

Pleurosigma sp.: Late October river plankter. Good growth at $5 \mathrm{mg} / 1$ sucrose with velocities of 0.71 and $0.56 \mathrm{ft} / \mathrm{sec}$.

Rotifers, Unidentified: Found in river plankton in July through October. Good channel growth at $5 \mathrm{mg} / 1$ sucrose and $0.56 \mathrm{ft} / \mathrm{sec}$ velocity.

Scenedesmus sp.: Present in river plankton in August through October. Fair channel growth at 5,10 and $20 \mathrm{mg} / \mathrm{l}$ sucrose at all velocities tested.

Stauroneis sp.: Rare in river plankton. Good channel growth with $5 \mathrm{mg} / 1$ sucrose with all velocities tested.

Stephanodiscus sp.: River plankter during July, August, and early September. Good channel growth at $5 \mathrm{mg} / \mathrm{l}$ sucrose with all velocities tested.

Stigeoclonium tenue: Not observed in river plankton. Excellent channel growth at 5 and $10 \mathrm{mg} / 1$ at $1 \mathrm{ft} / \mathrm{sec}$.

Surirella sp.: Rare in river plankton. Fair channel growth at $5 \mathrm{mg} / 1$ sucrose and $0.71 \mathrm{ft} / \mathrm{sec}$ velocity.

Synedra capitata: Rare in river plankton. Fair channel growth at $10 \mathrm{mg} / \mathrm{l}$ and $0.68 \mathrm{ft} / \mathrm{sec}$. 
Synedra acus: Rare in river plankton. Good channel growth at $5 \mathrm{mg} / \mathrm{l}$ sucrose and $0.71 \mathrm{ft} / \mathrm{sec}$ velocity.

Tabellaria fenestrata: Present in river plankton intermittently during early August and throughout September. Excellent channel growth at $10 \mathrm{mg} / 1$ sucrose and 0.25 $\mathrm{ft} / \mathrm{sec}$ velocity.

Ulothrix zonata: Not observed in river plankton. Growth noted in channel at 5 and $10 \mathrm{mg} / \mathrm{l}$ at $1 \mathrm{ft} / \mathrm{sec}$.

Vorticella sp.: Very rare in river plankton. Growth noted in channel during heavy Sphaerotilus growth.

It is likely that some individuals noted were chance associations, but the regularity of appearance of forms such as Melosira granulata, M. varians, Navicula, Nitzschia, Cosmarium and Euglena in the biological floc seems to indicate a closer relationship. The exact nature of this relationship would have to be determined through extensive laboratory investigation beyond the scope of present work. There is a definite symbiotic relationship between the floc and simuliid and tendipedid larvae and pupae, in that early growths of Sphaerotilus were noted to attach first to the mucous and silken strands of these forms, incorporating them as central "stems" in the feathery growth. These macroinvertebrates in turn, were furnished shelter and food by the flocs. The hydrophyllid beetles also took advantage of the shelter and food value of the flocs, but it is doubtful that they contributed anything in return.

The exact manner in which Sphaerotilus is able to take over and dominate a niche from an established population is still obscure. One observation worthy of note is that in the early hours of nutrient feed, Sphaerotilus became attached to growths of the green alga Spirogyra. Soon, gas bubbles, presumably photosynthetic oxygen, formed between the alga and flocs, but after the alga was blandeted enough to exclude light, gas bubbles formed between the liner and the alga, breaking the latter loose from its attachment and leaving a clean niche, which Sphaerotilus immediately moved in to occupy.

Generally, saturation population occurred in the channel around $72 \mathrm{hr}$ after feed was started. At temperatures of $20-28^{\circ} \mathrm{C}$ heaviest growths were obtained with $5 \mathrm{mg} / \mathrm{l}$ molasses, their magnitude being proportional to velocity, in the range of 1.49 to 0.58 $\mathrm{ft} / \mathrm{sec}$.

At temperatures below $20^{\circ} \mathrm{C}$, saturation population was not attained even after 12 days accumulation. In fact, at temperatures from $9-17^{\circ} \mathrm{C}$, Sphaerotilus was replaced in dominance by a small filamentous bacillus. It is the belief of the writer that a channel of some ten times greater length would be required to obtain saturation population at temperatures of $10-15^{\circ} \mathrm{C}$. This is based in part on the writer's observation of growths in the Altamaha (river) in Georgia over a three-year period. With a relatively constant load of modified Kraft process wastes, growths of Sphaerotilus during the winter months extended over some forty miles of river, reaching a maximum around 5 miles below the outfall. At summer temperatures $\left(28-30^{\circ} \mathrm{C}\right)$ however, growth receded to within one mile or less of the outfall, the maximum occurring just below that structure.

\section{CONCLUSIONS}

Sphaerotilus natans was stimulated to grow into bloom proportions by addition of $1 \mathrm{mg} / \mathrm{l}$ of sucrose to a natural water containing as little as $0.5 \mathrm{mg} / \mathrm{l}$ of total nitrogen and $0.001 \mathrm{mg} / \mathrm{l}$ of orthophosphate as phosphorus. 
The optimum concentration of sucrose for heavy growth of Sphaerotilus-dominated flocs in the channel was $5 \mathrm{mg} / \mathrm{l}$ at velocities of 0.58 to $1.49 \mathrm{ft} / \mathrm{sec}$ in the temperature range of $20-28^{\circ} \mathrm{C}$. Generally, growth was proportional to both temperature and velocity, and classical flocs did not occur in this system below $17^{\circ} \mathrm{C}$.

The biological floc community consisted of Sphaerotilus natans, the diatoms, Melosira granulata, $M$. varians, Navicula sp., Nitzschia sp.: the desmid, Cosmarium sp.; the green euglenoids, Euglena sp.; and usually the bacteria-feeding protozoans, Tetrahymena pyriformis, Colpidium colpoda; occasional amoebae; and often Bodo (caudatum?) sp. Both tendipedid and siluliid larval forms found a favorable habitat of shelter and food within the biological growths, and the mucous and silken threads of these invertebrates served as formation "nuclei" for Spaherotilus growth.

After receiving nutrient for $72-96 \mathrm{hr}$, growth in the channel reached a type of equilibrium, at which time, the amount of old growth detaching and floating away just equalled the amount of new growth being formed. The term "saturation population" was proposed to describe this condition. Just after saturation population, the growths were blackened with an odor of hydrogen sulfide, indicating a critical thickness of the floc at which time it was no longer permeable to diffusion of oxygen and/or other gases.

Acknowledgements-Major financial support for this investigation was provided as research grant WP. 00091 from the Division of Water Supply and Pollution Control, U.S. Public Health Service.

The authors wish to express their sincere appreciation to C. PRESTON WITCHER and the staff of the Ann Arbor Waste Treatment Plant and to the City of Ann Arbor for generously providing the use of space and equipment.

This paper is taken, in part, from a dissertation submitted by the senior author to the Graduate School of The University of Michigan in partial fulfillment of the requirements for the degree of Doctor of Philosophy.

\section{REFERENCES}

BüsGen M. (1894) Cultureversuche mit Cladothrix dichotoma. Ber. dt. bot. Ges. 12, 147-152.

ButCher R. W. (1932) Contribution to our knowledge of the ecology of sewage fungus. Trans. Br. mycol. Soc. 17, 112-123.

Butcher R. W. (1946) The biological detection of pollution. J. Proc. Inst. Sew. Purif. 2, 92-97.

Gannon J. J., Dirasian H. A. and Phaup J. D. (1966) A versatile outdoor channel for water pollution investigations. Proc. 21st Purdue Conf. Ind. Wastes. Engng. Ext. Ser. In press.

Harrison M. E. and HeukeleKIAN H. (1958) Slime infestation-literature review. Sew. ind. Wastes 30, 1278-1302.

JAAG O. and AMBÜHL H. (1963) Effect of the current on the biocoenoses in flowing streams. Air \& Wat. Pollut. Int. 7, 317-330.

LACKEY J. B. (1938) The manipulation and counting of river plankton and changes in some organisms due to formalin preservation. Publ. Hlth Repts, 53, 2080-2093.

LIEBMANN H. (1951) Handbuch der Frischwasser und Abwasserbiologie. Munich.

LiebManN H. (1963) The inhabitants of Sphaerotilus flocs and the physico-chemical basis for their formation. Vom Wass. 20, 24-33 (Wat. Pollut. Abstr. 28, 940).

McKeown J. J. (1962) The control of Sphaerotilus natans by a southern Kraft mill. Proc. 17th Purdue Conf. Ind. Wastes. Engng. Ext. Ser. 112, 440.

NaUmanN, E. (1933a) Report on the ecology of the freshwater algae. IV. The algae-aufwuchs of Sphaerotilus natans. Ark. Bot. No. 25A. (Translation)

NaumanN, E. (1933b) Über die Begutachtung des Aufwuchess von Sphaerotilus natans (Kützing) Arch. Hydrobiol. 25, 407-422.

PotonIE H. and WUNDSCH H. H. (1933) Quantitative values and typical manifestation of floating sewage fungus. Zeits. Fisch. 31, 379-389. 
Standard Methods for the Examination of Water and Waste Water (1965) 12th ed. American Public Health Association, New York.

WUHRMANN K. (1964) River bacteriology and the role of bacteria in self-purification of rivers. In Principles and Applications in Aquatic Microbiology, John Wiley, New York.

ZimmermanN P. (1961) Experimentelle Untersuchungen über die ökologische Wirkiung der Stromungsgeschwindigkeit auf die Lebensgemeinschaften des fliessenden Wassers. Schweiz. z. Hydrol. 23, $1-81$. 